\title{
Inulin as a growth promoter in diets for rabbits
}

\author{
Rocío Salas Montiel ${ }^{1}$, Irene Torres Acosta ${ }^{1}$, Enrique Villarreal Delgado ${ }^{1}$, María Eugenia \\ Juárez-Silva ${ }^{1}$, Alejandro Azaola ${ }^{2}$, Fernando Pérez-Gil Romo ${ }^{1}$
}

\footnotetext{
${ }^{1}$ Instituto Nacional de Ciencias Médicas y Nutrición Salvador Zubirán, Tlalpan, México DF.

${ }^{2}$ Departamento Sistemas Biológicos, Universidad Autónoma Metropolitana, Coyoacán, México DF.
}

\begin{abstract}
Sixty New Zealand rabbits aged 40 days were divided into 4 groups of 15 animals. The control group received a free diet of antibiotic growth promoter (AGP) and inulin. The second group was supplemented with $2.5 \mathrm{~g} / \mathrm{kg}$ of inulin. The third was administered AGP with $0.1 \mathrm{~g} / \mathrm{kg}$ of flavomycin. Finally, the fourth group received a $2.5 \mathrm{and} 0.1 \mathrm{~g} / \mathrm{kg}$ inulin/AGP diet. Body weight gain was higher in the control group. Rabbits supplemented with inulin had lower values of triglycerides compared with the control and AGP groups, and their glucose level was significantly lower than those treated with AGP. Additionally, serum calcium and magnesium concentrations were higher than the other groups, particularly with regard to AGP. The bone content with regard to calcium, phosphorus and magnesium in the groups treated with inulin was higher compared with the control; moreover, phosphorus and magnesium were higher than in the AGP group. The thickness of the mucosa and crypt depth in the caecum were significantly higher in rabbits treated with inulin than in the other groups, but especially compared with the AGP group. Also, triglyceride values were lower for rabbits treated with inulin/AGP than for those treated with AGP and the bone magnesium concentration was significantly higher compared with the control group. In addition, inulin was shown to have positive effects on the rabbit, promoting increase in bone and serum calcium, magnesium and phosphorus, decrease in triglyceride levels, and improvement in the caecum (changes in morphology, crypt depth and mucosal thickness).
\end{abstract}

Key Words: bone, caecal, crypts, diet, inulin, minerals, mucosa

\section{Introduction}

The use of low-dose antibiotics as growth promoters in animal production has been linked to the resistance of some bacteria and public health implications (Allen et al., 2011; Huber et al., 2011). Since 2006, the EU has decided to withdraw the use of antibiotics as animal growth promoters (AGP) (Torres \& Zarazaga, 2002; European Union, 2003). Flavomycin is an antibiotic that is often used as an AGP in pig, poultry and ruminant production systems (Van der Merwe et al., 2001; Edwards et al., 2005). Animal growth promoter abuse results in the necessity to test natural products such as inulin (Maertens, 2008; Chu et al., 2011) that selectively stimulate the growth of beneficial commensal microbiota, including bifidobacteria and lactobacilli (Roberfroid et al., 2010); this probiotic reduces the risk of infection as a result of exerting a protective effect against opportunistic enteropathogenic bacteria (Verdonk et al., 2005; VeeremanWauters et al., 2011).

The effect of inulin on the regulation of blood glucose and lipid metabolism has been studied (Delzenne et al., 2002; Verbrugghe et al., 2009). It also stimulates the absorption of calcium and magnesium, which helps to strengthen the skeletal system (Scholz-Ahrens \& Schrezenmeir, 2002), because the degradation of inulin by bifidobacteria and lactobacilli increases the production of volatile fatty acids (VFA), acidifies the microenvironment of the large intestine and increases the ionized and soluble fraction of the present minerals, facilitating its absorption (Demigné et al., 2008; Varley et al., 2010).

Rabbits experimentally infected with E. coli 0103 and supplemented with oligofructose have shown better responses to infection than the control group, which have also shown decreased $\mathrm{pH}$ and increased VFA concentration (Morisse et al., 1993).

Maertens et al. (2004) and Juskiewicz et al. (2007) reported that the employment of fructo-oligosaccharides or inulin in the diet of rabbits produced an increase in volatile fatty acids. In accordance with previous studies, inulin inclusion is used to avoid possible gastrointestinal infections and may be an alternative to the use of AGP. The objective of this study was to evaluate the effect of inulin inclusion on calcium, magnesium and phosphorus amounts in the femur, serum biochemical parameters, and the thickness of the mucosa, as well as the depth of crypts of the caecum. 


\section{Material and Methods}

Sixty New Zealand rabbits aged 40 days, weighing $889.2 \pm 173.8 \mathrm{~g}$ on average, obtained from an experimental farm at Universidad Nacional Autónoma de México, were randomly divided into four groups, each with 15 animals. Different treatments were assigned to the groups (Table 1). The rabbits were placed individually in stainless steel cages under controlled temperature conditions $\left(15\right.$ to $\left.22^{\circ} \mathrm{C}\right)$ with adequate room ventilation and periods of $14 \mathrm{~h}$ light and $10 \mathrm{~h}$ darkness. Diets and water were provided ad libitum throughout the study period until slaughter at 42 days. Weight measurements were always taken between 8 and 9 a.m., before the feed was supplied, and the weight gain of rabbits was estimated.

Tables of the nutritional requirements for the fattening of rabbits from the NRC (1977) and de Blas \& Mateos (2010) were consulted for the elaboration of the experimental diets (Table 1). The antibiotic growth promoter used was flavophospholipol (flavomycin), at a final concentration of $4 \mathrm{ppm}$ in the two diets that contained it (Flaveco $40^{\circledR}, 40 \mathrm{~g}$ of flavomycin/ $\mathrm{kg}$ ) (European Union, 1999). Inulin inclusion (Inulina IPS Raftifeed ${ }^{\circledR}$, Orafti) in two of the four diets was at a concentration of $2.5 \mathrm{~g} / \mathrm{kg}$. Each treatment was prepared by mixing the individual ingredients before carrying out a chemical analysis on each of the four resulting experimental diets.

Rabbits were sacrificed by cervical dislocation, following the procedure described by NOM-062-ZOO-1999 (Mexican Official Norm, 2001). Immediately, a blood sample was obtained from each animal by cardiac puncture with a $10 \mathrm{~mL}$ disposable syringe, transferred to tubes with gel and centrifuged at 3,500 rpm for 10 minutes. The serum was stored at $4{ }^{\circ} \mathrm{C}$, in order to measure glucose, triglyceride, cholesterol, calcium, magnesium and phosphorus levels.

The ash content was determined by combustion for $1 \mathrm{~h}$ at $550{ }^{\circ} \mathrm{C}$ (AOAC cod. 923.03, 2003). Ether extract was extracted by diethyl ether anhydrus using a Soxhlet apparatus (AOAC 920.15 and 963.39, 2003). Crude protein was measured by Kjeldahl nitrogen analysis (AOAC cod 976.05, 2003). The neutral detergent fiber (NFD), acid detergent fiber (ADF) and acid detergent lignin (ADL) contents were determined according to the Ankom method, following the protocol of manufacturer, using filter bags model F-57 (Ankom Technology, NY, USA). Energy was calculated for each diet in a Parr Calorimeter model 1241 (Parr Instrument Company, IL, USA), following the protocol of the manufacturer (1966).

Bone samples for the analysis of $\mathrm{Ca}, \mathrm{Mg}$ and $\mathrm{P}$ were obtained from the femur of 9 rabbits taken at random from each treatment. Bones were fleshed and degreased in chloroform for subsequent drying in an oven at $60{ }^{\circ} \mathrm{C}$ for 48 hours and then pulverized in a mill (Thomas Scientific Mod 174931). Powdered samples of femur $(0.1 \mathrm{~g})$ were subjected to a sequential wet digestion technique according to AOAC 975.03 (2005), using nitric acid (5 mL) followed by perchloric acid $(3 \mathrm{~mL})$ and hydrochloric acid $(0.5 \mathrm{~mL})$; in each case the sample was heated to boiling until evaporation, using a Microkjeldahl grid, with six $100 \mathrm{~mL}$ flasks. The determination of $\mathrm{Ca}$ and $\mathrm{Mg}$ was performed by atomic absorption spectrometry (Perkin Elmer Mod. Analyst $800)$. For the measurement of phosphorus, the photometric method AOAC 986.24 (2005) was used. All samples were quantified in triplicate.

Table 1 - Calculated composition of the four experimental diets

\begin{tabular}{|c|c|c|c|c|}
\hline Ingredients & Control (g/kg) & Inulin $(\mathrm{g} / \mathrm{kg})$ & $\mathrm{AGP}(\mathrm{g} / \mathrm{kg})$ & Inulin/AGP $(\mathrm{g} / \mathrm{kg})$ \\
\hline Corn & 116 & 116 & 116 & 116 \\
\hline Wheat bran & 251 & 251 & 251 & 251 \\
\hline Soybean meal & 129 & 129 & 129 & 129 \\
\hline Soybean oil & 31 & 31 & 31 & 31 \\
\hline Alfalfa & 438 & 438 & 438 & 438 \\
\hline Calcium phosphate & 10 & 10 & 10 & 10 \\
\hline Vitamin and minerals premix ${ }^{1}$ & 1.0 & 1.0 & 1.0 & 1.0 \\
\hline Antioxidant BHT & 0.01 & 0.01 & 0.01 & 0.01 \\
\hline Potassium sorbate fungicide & 0.01 & 0.01 & 0.01 & 0.01 \\
\hline Inulin & 0 & 2.5 & 0 & 2.5 \\
\hline Flaveco $40^{\circledR 2}$ & 0 & 0 & 0.1 & 0.1 \\
\hline Coccidiostat $^{4}$ & 0.5 & 0.5 & 0.5 & 0.5 \\
\hline Binder $^{3}$ & 20 & 20 & 20 & 20 \\
\hline Sodium chloride & 5.0 & 5.0 & 5.0 & 5.0 \\
\hline
\end{tabular}

${ }^{1}$ Vitamin and mineral premix content in grams per kilogram: vit $\mathrm{A}$ - 32,000 IU; vit D - 4,000 IU; vit E - $4.0 \mathrm{~g}$; vit $\mathrm{K} 3$ - $4.0 \mathrm{~g}$; vit $\mathrm{B}_{1}$ - $8.0 \mathrm{~g}$; vit $\mathrm{B}_{2}$ - $8.0 \mathrm{~g}$; vit $\mathrm{B}_{6}$ - $8.0 \mathrm{~g}$; vit $\mathrm{B}_{12}$ - $40.0 \mathrm{~g}$; biotin - $200 \mathrm{mg}$; pantothenic acid - $40.0 \mathrm{~g}$; iron - 4,000 mg; copper - $600 \mathrm{mg}$; cobalt - $100 \mathrm{mg}$; zinc - $6,000 \mathrm{mg}$; manganese - $4,300 \mathrm{mg}$; iodine - $32 \mathrm{mg}$; selenium - $8 \mathrm{mg}$ (BASF from Mexico).

${ }^{2}$ Flaveco $40^{\circledR}$ contains $40 \mathrm{~g}$ of flavophospholipol per kg.

${ }^{3}$ Carboxymethyl cellulose.

${ }^{4}$ Coccidiostat robenidine hydrochloride at $33 \mathrm{ppm}$ (Alpharma AS).

AGP - antibiotic growth promoter. 
For determination of serum $\mathrm{Ca}$ and $\mathrm{Mg}, 0.5 \mathrm{~mL}$ of each sample was taken and homogenized with $1.5 \mathrm{~mL}$ lanthanum oxide $(0.1 \%)$ and absorbance was read in an atomic absorption spectrophotometer. For serum phosphorus, glucose, triglyceride and cholesterol determination, SYNCHRON CX ${ }^{\circledR}$ kits were used.

Once euthanasia was performed, the tissues were dissected by taking a caecum portion $(10 \mathrm{~cm})$ from the proximal segment. Samples of freshly digested tissue were used for the immediate determination of $\mathrm{pH}$, and the rest was removed. Subsequently, this portion was rinsed with physiological saline solution and preserved in $10 \%$ formalin. From each segment, $0.5 \mathrm{~cm}$ transverse portions were taken by cutting with a microtome for haematoxylineosin staining; these were embedded in paraffin. Intestinal mucosa and crypts were characterized by optical microscopy with a $2.5 \mathrm{X}$ objective, performing the measurement of mucosal thickness and depth of caecal crypts with the Automated Morphometry package (Q Leica 500/Win). The caecal epithelium width had 10 random measurements, completing 50 measurements for each treatment group.

Data are expressed as mean values \pm standard deviation of the mean (SD). The results were processed statistically using the variance of a test track, and the difference between groups was determined by Tukey's multiple tests with a significance of $\mathrm{P} \leq 0.05$. For data that did not show a normal distribution, nonparametric Mann-Whitney $U$ and Kruskal-Wallis tests were used. For this purpose, the statistical package SPSS 15 (Statistical Package for Social Science) was used.

\section{Results and Discussion}

The digestible energy was greater in the rabbits supplemented with inulin compared with the other groups (Table 2). Furthermore, the neutral detergent fiber (NDF) was higher in the groups studied than that observed by de Blas et al. (2002).
Digestible energy was higher in the two treatments with inulin, probably due to their prebiotic effect observed in digestible energy values (Table 2), which was higher for the diet with inulin than the inulin/AGP group, which might be due to the antibiotic effect on the intestinal microbiota. Although the digestion energy of the inulin group was high, this was not reflected in weight gain since the control group presented a significantly greater weight gain than the groups Inulin, AGP and Inulin/AGP $(\mathrm{P}<0.05$ and $\mathrm{P}<0.01$, respectively) (Table 3 ).

Acetic fermentation occurs in the cecum and utilizes the carbohydrates derived from the fiber as the main source of energy. Furthermore, a great part of this fiber directly intervenes in the accumulation of cecal digesta due to its effect on intestinal motility.

It has been reported that in concentrations of $387 \mathrm{~g} / \mathrm{kg}$ of NDF, the cecal content is minimal and feed intake increases, consequently improving growth; however, to the contrary, in the present study, high concentrations of NDF were observed in all treatments, resulting in greater cecal digesta, and thus lower feed intake, causing a reduction in weight gain (de Blas et al., 2002). The above coincides with the reports of Fabre et al. (2002), who, increasing the level of fiber to $41 \%$, observed a reduction in carcass weight.

In the present study, no reports of ailing or dead rabbits were registered, possibly as a result of the high level of fiber in the diets which favored a more active renovation of the digesta in the cecum, sufficient to reduce pathogenic gut flora in all groups (García et al., 2000) and also in the case of the rabbits treated with inulin by its prebiotic effect.

In addition, in this study, the $\mathrm{pH}$ in the digested caecum from rabbits supplemented with inulin only and in combination with AGP decreased $(\mathrm{P}<0.05$; Table 3). This could be because of microbial fermentation of inulin, which causes an increase in volatile fatty acids (acetic, propionic and butyric acids), and in turn suggests greater proliferation of beneficial bacterial species, and a decrease in the competitive exclusion of pathogenic species in the

Table 2 - Chemical analysis of the diets

\begin{tabular}{lcccc}
\hline Ingredients & Control & Inulin & AGP & Inulin/AGP \\
\hline Dry matter $(\mathrm{g} / \mathrm{kg})$ & 945 & 926 & 939 & 920 \\
Ether extract $(\mathrm{g} / \mathrm{kg})$ & 39 & 30 & 29 & 42 \\
Crude protein $(\mathrm{g} / \mathrm{kg})$ & 169 & 169 & 168 & 170 \\
Ash $(\mathrm{g} / \mathrm{kg})$ & 104 & 102 & 101 & 102 \\
Neutral detergent fiber $(\mathrm{g} / \mathrm{kg})$ & 525 & 530 & 517 & 514 \\
Acid detergent fiber $(\mathrm{g} / \mathrm{kg})$ & 224.6 & 201.7 & 192.7 & 250 \\
Lignin $(\mathrm{g} / \mathrm{kg})$ & 120 & 92 & 310 & 323 \\
Hemicellulose $(\mathrm{g} / \mathrm{kg})$ & 305 & 328 & 11.7 & 120 \\
Digestible energy $(\mathrm{MJ} / \mathrm{kg})$ & 10.8 & 13.5 & & 12.8 \\
\hline AGP & & &
\end{tabular}

AGP - antibiotic growth promoter. 
digestive tract, resulting in improved health of the rabbit (Flickinger \& Fahey, 2002; Juskiewicz et al., 2007).

Rabbits supplemented with inulin had higher concentrations of calcium, magnesium and phosphorus in the femur (Table 4). Calcium was also significantly higher than in the control group $(\mathrm{P}<0.01)$, while animals supplemented with inulin showed higher phosphorus values than the control and AGP groups ( $\mathrm{P}<0.01$ and $\mathrm{P}<0.05$, respectively). In the case of magnesium, the levels were higher compared with those treated with AGP and the control group $(\mathrm{P}<0.05$, $\mathrm{P}<0.01$, respectively). Also, a higher concentration of magnesium was observed in those treated with inulin/AGP in comparison with the control $(\mathrm{P}<0.05)$.

The relative increases in calcium, magnesium and phosphorus in the bone might be related to the indirect effect associated with microbial fermentation in the caecum, which is increased by inulin supplementation and volatile fatty acid production; this facilitates the absorption of minerals via trans epithelial transport due to induced $\mathrm{pH}$ decreases which changes the solubility of calcium, magnesium and phosphorus in the intestinal lumen, facilitating transport across the epithelium (Younes et al., 2001; Lobo et al., 2006; Scholz-Ahrens \& Schrezenmeir, 2007). The short-chain fatty acids contribute directly to the increased absorption of calcium, phosphorus and magnesium through a cation- exchange mechanism (Ladislav \& Hannelore, 2005; Raschka \& Daniel, 2005) and there is evidence that narrow bonds (tight junctions), located on the luminal side, adjacent to epithelial cells, regulate the absorption of several nutrients including calcium (Mineo et al., 2002; Pérez et al., 2008). In this regard, another pathway that may explain the increased mineral absorption is the trophic effect of inulin on the intestine, due to cell proliferation, especially as a result of the increased production of butyrate (Goñi \& López-Oliva, 2006; Kien et al., 2007).

Serum glucose and triglyceride levels were different between the groups. The two treatments with inulin had lower glucose levels than AGP $(\mathrm{P}<0.01)$. Similarly, treatments with inulin and inulin/AGP showed lower triglyceride levels compared with the AGP group $(\mathrm{P}<0.01$ and $\mathrm{P}<0.05$, respectively; Table 5).

Serum cholesterol did not differ among the groups treated with inulin and control. However, the values of the control group were significantly lower than those for the inulin/AGP and AGP groups $(\mathrm{P}<0.05$ and $\mathrm{P}<0.01$, respectively; Table 5).

Rabbits supplemented with inulin showed a decrease in postprandial serum triglycerides, which could be explained by the indirect effect of inulin on lipid metabolism, due to the reduction of triglycerides by increased caecal VFA

Table 3 - Weight in vivo and $\mathrm{pH}$ of caecal contents of rabbits

\begin{tabular}{lcccc}
\hline Ingredients $^{1}$ & Control & Inulin & AGP & Inulin/AGP \\
\hline Initial weight $(\mathrm{g})$ & $790.7 \pm 149.9$ & $788.3 \pm 101.5$ & $858.4 \pm 218.6$ & $1078.9 \pm 72.2$ \\
Final weight $(\mathrm{g})$ & $2268.5 \pm 63.5$ & $1938.8 \pm 126.7$ & $2035.6 \pm 63.5$ & $2170.1 \pm 20.6$ \\
Weight gain (g/day) & $34.7 \pm 2.5 \mathrm{a}$ & $* 29.8 \pm 1.5 \mathrm{~b}$ & $* * 26.6 \pm 5.6 \mathrm{~b}$ & $* * 26.4 \pm 2.7 \mathrm{~b}$ \\
$\mathrm{pH}$ & $6.7 \pm 0.19 \mathrm{a}$ & $\dagger 6.3 \pm 0.20 \mathrm{bc}$ & $\dagger 6.8 \pm 0.28 \mathrm{a}$ & $6.5 \pm 0.29 \mathrm{~b}$ \\
\hline
\end{tabular}

${ }^{1}$ Estimates followed by different letters in the same row differ, ${ }^{*} \mathrm{P}<0.05$, ${ }^{*} * \mathrm{P}<0.01$ (Tukey) and $\dagger \mathrm{P}<0.05$ (U Mann-Whitney).

AGP - antibiotic growth promoter.

Table 4 - Bone mineral content in rabbits

\begin{tabular}{|c|c|c|c|c|}
\hline Ingredients $^{1}$ & Control & Inulin & AGP & Inulin/AGP \\
\hline Phosphorus (g/100 g of bone) & $7.9 \pm 1.0 \mathrm{c}$ & $* * 9.1 \pm 0.36 \mathrm{a}$ & $* 8.2 \pm 0.33 b c$ & $8.5 \pm 0.56 \mathrm{ab}$ \\
\hline Calcium (g/100 g of bone) & $18.3 \pm 1.60 \mathrm{~b}$ & $* * 20.1 \pm 0.77 \mathrm{a}$ & $18.9 \pm 0.61 \mathrm{ab}$ & $19.0 \pm 1.17 \mathrm{ab}$ \\
\hline Magnesium (g/100 g of bone) & $0.37 \pm 0.05 c$ & $* * 0.42 \pm 0.02 \mathrm{a}$ & $* 0.39 \pm 0.02 b c$ & $* 0.41 \pm 0.01 \mathrm{ab}$ \\
\hline
\end{tabular}

${ }^{1}$ Estimates followed by different letters in the same row differ, $* \mathrm{P}<0.05$ and $* * \mathrm{P}<0.01$ (Tukey).

AGP - antibiotic growth promoter.

Table 5 - Serum parameters in rabbits fed the experimental diets

\begin{tabular}{|c|c|c|c|c|}
\hline Ingredients ${ }^{\mathbf{1}, \mathbf{2}}$ & Control & Inulin & AGP & Inulin/AGP \\
\hline Glucose $(\mathrm{mg} / \mathrm{dL})$ & $142.7 \pm 13.2 \mathrm{ab}$ & $136.7 \pm 7.8 \mathrm{c}$ & $* * 157.0 \pm 14.0 \mathrm{a}$ & $137.1 \pm 6.51 \mathrm{c}$ \\
\hline Cholesterol (mg/dL) & $58.1 \pm 11.7 \mathrm{c}$ & $65.4 \pm 8.9 b c$ & $\dagger \dagger 81.1 \pm 15.2 \mathrm{a}$ & $\dagger 71.9 \pm 13.3 \mathrm{ab}$ \\
\hline Triglycerides (mg/dL) & $71.1 \pm 19.67 \mathrm{ab}$ & $\dagger 45.5 \pm 18.7 \mathrm{c}$ & $\dagger \dagger 84.4 \pm 5.4 \mathrm{a}$ & $\dagger 56.4 \pm 25.9 \mathrm{c}$ \\
\hline Calcium (mg/dL) & $9.6 \pm 3.0 \mathrm{ab}$ & $* 13.9 \pm 2.5 \mathrm{a}$ & $* 6.2 \pm 1.0 \mathrm{c}$ & $* 9.4 \pm 2.6 \mathrm{ab}$ \\
\hline Magnesium (mg/dL) & $2.1 \pm 0.2 b$ & $* * 2.9 \pm 0.8 \mathrm{a}$ & $* 1.8 \pm 0.3 \mathrm{c}$ & $* * 2.0 \pm 0.3 \mathrm{bc}$ \\
\hline Phosphorus (mg/dL) & $7.5 \pm 1.1$ & $8.43 \pm 1.7$ & $7.6 \pm 1.6$ & $7.7 \pm 2.0$ \\
\hline
\end{tabular}

${ }^{1}$ Estimates followed by different letters in the same row differ, ${ }^{*} \mathrm{P}<0.05$ and $* * \mathrm{P}<0.01$ (Tukey).

${ }^{2}$ Estimates followed by different letters in the same row differ, $\uparrow \mathrm{P}<0.05$ and $\uparrow \uparrow \mathrm{P}<0.01$ (U Mann-Whitney).

AGP - antibiotic growth promoter. 
Table 6 - Mucosal thickness and crypt in the caecum

\begin{tabular}{lcccc}
\hline Ingredients $^{1}$ & Control & Inulin & AGP & Inulin/AGP \\
\hline Thickness of mucosa $(\mu \mathrm{m})$ & $182.8 \pm 39.1 \mathrm{~b}$ & $231.4 \pm 63 \mathrm{a}$ & $83.3 \pm 12 \mathrm{~cd}$ & $103.8 \pm 24.5 \mathrm{c}$ \\
Crypt depth $(\mu \mathrm{m})$ & $106.4 \pm 22.7 \mathrm{~b}$ & $136.1 \pm 39.1 \mathrm{a}$ & $47.9 \pm 8.5 \mathrm{~cd}$ & $60.4 \pm 16.6 \mathrm{c}$ \\
\hline
\end{tabular}

${ }^{1}$ Estimates followed by different letters in the same row differ, $\mathrm{P}<0.01$ (Tukey). AGP - antibiotic growth promoter.

production, mainly propionate; this is reported to inhibit fatty acid synthesis by decreasing cholesterol and triglyceride levels (Lin et al., 1995; Hosseini et al., 2011). The AGP group had higher levels of triglycerides, cholesterol and glucose, which is consistent with Edwards et al. (2005), who suggested an inhibitory effect of this antibiotic on the beneficial commensal microflora with decrease in the production of VFA (Table 5).

Rabbits supplemented with inulin showed higher levels of magnesium and calcium with respect to the other treatments, but in particular in comparison with the AGP group $(\mathrm{P}<0.01)$. Phosphorus did not show any significant differences (Table 5).

Rabbits supplemented with inulin had higher levels of calcium, magnesium and phosphorus in bone and serum (Tables 4 and 5); an estimate of the increase was observed for bone calcium and phosphorus (10\% and $15 \%$, respectively), whereas serum calcium increased by $45 \%$. Although no significant differences in serum phosphorus concentrations were seen among treatments, a $12 \%$ increase was estimated in the group treated with inulin. This is consistent with studies in rats, which showed that the intake of inulin and fructooligosaccharides increased the absorption of calcium, magnesium and phosphorus (Scholz-Ahrens \& Schrezenmeir, 2007; Demigné et al., 2008; Lobo et al., 2009).

In relation to magnesium, rabbits treated with inulin had estimated concentration increases of $38 \%$ in serum and $13.5 \%$ in the bone when compared with the control group (Tables 4 and 5). For the group of inulin/AGP, increased magnesium in bone was similar to the inulin group $(11 \%)$; these results are similar to those reported by Takahara et al. (2000), who found an increase in magnesium in the femur of growing rats on a diet supplemented with fructooligosaccharides at a rate of $50 \mathrm{~g} / \mathrm{kg}$. In contrast, the AGP-treated group had an estimated decline of $35 \%$ calcium and $14.3 \%$ in serum magnesium, which was associated with an increase in the $\mathrm{pH}$ of the digested caecum, perhaps due to less dissociation of minerals and therefore a decrease in the absorption (Table 5). This could be explained by the results of Edwards et al. (2005), who observed a decrease in total VFA and increased $\mathrm{pH}$ in the rumen of flavomycin sheep.

Histological examination of the caecum showed that the inulin-supplemented group had greater mucosal thickness and crypt depth than the other groups, especially with respect to the AGP group $(\mathrm{P}<0.01)$ (Table 6).

Supplementation of the diet with inulin promoted thickening of the caecum in relation to other groups and in particular for the AGP group $(\mathrm{P}<0.01$; Table 6). This increase is linked to the production of VFA and especially butyric acid, which directly affects the lining of the intestine to promote cell proliferation; this, in turn, promotes increase in thickness. It also increases the microcirculation of the mucosa and consequently increases the surface absorption of minerals and nutrients, thereby strengthening the intestinal and systemic health of the rabbits (Scheppach et al., 1994; Blotiêre et al., 2003; Metzler \& Mosenthin, 2008).

An increase in crypt depth was also observed in the group supplemented with inulin. This increase may reflect the thickening of the protective layer that lines the luminal surface as a result of increased mucin as well as an increase in regenerative epithelial cells and greater absorption of electrolytes (Kleessen et al., 2003). In contrast, the decrease in crypt depth was especially apparent in rabbits treated with AGP. The consequent adverse effects on the crypts and caecal mucosa could cause functional impairment of the caecal luminal surface due to the use of AGP. Also, groups treated with AGP had a significantly lower mucosal thickness than the other groups $(\mathrm{P}<0.01)$, which could also affect the absorption of nutrients and minerals due to the reduced area of contact of the mucosa (Table 6).

\section{Conclusions}

Rabbits supplemented with inulin show higher concentrations of calcium, magnesium and phosphorus, both in serum and bone, reduction in triglycerides, and favorable caecal morphology. Flavomycin reduces the serum $\mathrm{Ca}$ and $\mathrm{Mg}$, increases glucose, triglycerides and cholesterol levels and also reduces the thickness of the mucosa and caecal crypt depth, producing a negative effect on the status of the rabbits. Inulin/flavomycin show greater bone magnesium concentrations and a decrease in triglyceride and increase in cholesterol levels; however, despite the beneficial effect of inulin, the results show a decrease in mucosal thickness and crypt depth. In addition, high levels of fiber in the diets, as those used in the present study, might reduce the 
liveweight gain of the animals. Therefore, the use of inulin in the diet of rabbits could be an alternative to the use of antibiotics as growth promoters.

\section{References}

ALLEN, S.E.; BOERLIN, P.; JANECKO, N. et al. Antimicrobial resistance in generic Escherichia coli isolates from wild small mammals living in swine farm, residential, landfill, and natural environments in Southern Ontario, Canada. Applied Environmental Microbiology, v.77, p.882-888, 2011.

ASSOCIATION OF OFFICIAL ANALYTICAL CHEMISTRY AOAC. Official methods of analysis. 17.ed. Arlington: AOAC International, 2003.

ASSOCIATION OF OFFICIAL ANALYTICAL CHEMISTRYAOAC Official methods of analysis. 18.ed. Arlington: AOAC International, 2005.

BLOTIÊRE, H.M.; BUECHER, B.; GALMICHE, J.P. et al. Molecular analysis of the effect of short-chain fatty acids on intestinal cell proliferation. Proceedings of the Nutrition Society, v.62, p.101-106, 2003.

CHU, G.M.; LEE, S.J.; JEONG, H.S. et al. Efficacy of probiotics from anaerobic microflora with prebiotics on growth performance and noxious gas emission in growing pigs. Animal Science Journal, v.82, p.282-290, 2011

DE BLAS, C.; GARCÍA, J.; GÓMEZ-CONDE, S. et al. Restricciones a la formulación de piensos para minimizar la patología digestiva en conejos. In: XVIII Curso de Especialización FEDNA. Barcelona, España, 2002. p.71-93.

DE BLAS, C.; MATEOS, G.G. Feed formulation. In: DE BLAS, C.; WISEMAN, J. (Eds.) Nutrition of the rabbit. 2.ed. Wallingford, UK: CAB International, 2010. p.222-232.

DELZENNE, N.M.; DAUBIOUL, C.; NEYRINCK, A. et al. Inulin and oligofructose modulate lipid metabolism in animals: review of biochemical events and future prospects. British Journal of Nutrition, v.87, suppl 2, p.S255-S259, 2002.

DEMIGNÉ, C.; JACOBS, H.; MOUNDRAS, C. et al. Comparison of native or reformulated chicory fructans, or non-purified chicory, on rat caecal fermentation and mineral metabolism. European Journal of Nutrition, v.47, p.366-374, 2008

EDWARDS, J.E.; BEQUETTE, B.J.; McKAIN, N. et al. Influence of flavomycin on microbial numbers, microbial metabolism and gut tissue protein turnover in the digestive tract of sheep. British Journal of Nutrition, v.94, p.64-70, 2005.

EUROPEAN UNION AND EUROPEAN PARLIAMENT. On additives for use in animal nutrition, Regulation EC No 2562/1999, Europe Publication Office, L 310/11, Ginebra, 1999.

EUROPEAN UNION AND EUROPEAN PARLIAMENT. On additives for use in animal nutrition, Regulation EC No. 1831/2003, Europe Publications Office, L 268/29, Ginebra, 2003.

FABRE, C.; JUVERO, M.A.; BLAS, E. et al. Utilización de un pienso rico en fibra digestible y pobre de almidón en conejos de engorde: ensayo en condiciones de campo. In: SYMPOSIUM DE CUNICUlTURA, 31., 2002, Lorca. Proceedings... Canet de Mar, Spain: ASESCU, 2002. p.67-72.

FLICKINGER, E.A.; FAHEY Jr., G.C. Pet food and feed applications of inulin, oligofructuose and other oligosaccharides. British Journal of Nutrition, v.87, Suppl.2, p.S297-S300, 2002.

GARCÍA, J.; CARABAÑO, R.; PÉREZ-ALBA, L. et al. Effect of fiber source on cecal fermentation and nitrogen recycled through cecotrophy in Rabbits. Journal Animal Science, v.78, p.638-646, 2000.

GOÑI, I.; LÓPEZ-OLIVA, E. Carbohydrates and intestinal health. In: LAJOLO, F.M.; MENEZES, E.W. (Eds.) Carbohydrates in Iberoamericans regional foods. São Paulo: Universidade de São Paulo, 2006. p.208-210.
HOSSEINI, E.; GROOTAERT, C.; VERSTRAETE, W. et al. Propionate as a health-promoting microbial metabolite in the human gut. Nutrition Reviews, v.69, p.245-258, 2011.

HUBER, H.; ZIEGLER, D.; PFLUUGER, V. et al. Prevalence and characteristics of methicillin resistant coagulase-negative staphylococci from livestock, chicken carcasses, bulk tank milk, minced meat, and contact persons. BMC Veterinary Research, v.7, p.1-7, 2011.

JUSKIEWICZ, J.; ASMANSKAITE, L.; ZDUNCZYK, Z. et al. Metabolic response of the gastrointestinal tract and serum parameters of rabbits to diets containing chicory flour rich in inulin. Journal Animal Physiology and Animal Nutrition, v.92, p.113-120, 2007.

KIEN, C.L.; BLAUWIEKEL, R.; BUNN, J.Y. et al. Caecal infusion of butyrate increases intestinal cell proliferation in piglets. Journal of Nutrition, v.13, p.916-922, 2007.

KLEESSEN, B.; HARTMANN, L.; BLAUT, M. Fructans in the diet cause alterations of intestinal mucosal architecture, released mucins and mucosa-associated bifidobacteria in gnotobiotic rats. British Journal of Nutrition, v.89, p.597-606, 2003.

LADISLAV, R.; HANNELORE, D. Mechanisms underlying the effects of inulin-type fructans on calcium absorption in the large intestine of rats. Bone, v.37, p.728-735, 2005.

LIN, Y.; VONK, R.J.; SLOOFF, M.J. et al. Differences in propionate induced inhibition of cholesterol and triacylglycerol synthesis between human and rat hepatocytes in primary culture. British Journal of Nutrition, v.74, p.197-207, 1995.

LOBO, A.R.; COLLI, C.; FILISETTI, M.C. Fructo-oligosaccharides improve bone mass and biomechanical properties in rats. Nutrition Research, v.26, p.413-20, 2006

LOBO, A.R.; COCATO, M.L.; JORGETTI, V. et al. Changes in bone mass, biomechanical properties, and microarchitecture of calciumand iron-deficient rats fed diets supplemented with inulin-type fructans. Journal Nutrition Research, v.29, p.873-881, 2009.

MAERTENS, L.; AERTS, J.M.; DE BOEVER, J. Degradation of dietary oligofructose and inulin in the gastro-intestinal tract of the rabbit and the effects on caecal $\mathrm{pH}$ and volatile fatty acids. World Rabbit Science, v. 12, p.235-246, 2004.

MAERTENS, L. Strategies for the reduction of antibiotic utilisation during rearing. In: Giornate di Conglicoltura ASIC, 2007, Foli Italy. World Rabbit Science, v.16, p.111-120, 2008.

METZLER, B.U.; MOSENTHIN, R.A. Review of interactions between dietary fibre and the gastrointestinal microbiota and their consequences on intestinal phosphorus metabolism in growing pigs. Asian Australian Journal Animal Science, v.21, p.603-615, 2008 .

MINEO, H.; HARA, H.; SHIGEMATSU, N. et al. Melibiose, difructose anhydride III and difructose anhydride IV enhance net calcium absorption in rat small and large intestinal epithelium by increasing the passage of tight junctions in vitro. Journal Nutrition, v.132, p.3394-3399, 2002.

MORISSE, J.P.; MAURICE, R.; BOILLETOT, E. et al. Assessment of the activity of fructo-oligosaccharides on different caecal parameters in rabbits experimentally infected with E. coli $\mathrm{O} 103$. Annales Zootechnie, v.42, p.81-87, 1993.

NATIONAL RESEARCH COUNCIL - NRC. Nutrient requirements of rabbits. 2.rev.ed. Washington, D.C.: National Academy Press, 1977.

MEXICAN OFFICIAL NORM. NOM-062-ZOO-1999. Technical specifications for the production, care and use of laboratory animals. Official Journal of the Federation, 1, 22 de August de 2001.

PARR INSTRUMENT COMPANY. Oxygen bomb calorimetric and combustion methods. Moline, Illinois: Parr Instrument Company, 1966. (Technical manual No. 130).

PÉREZ, A.V.; PICOTTO, G.; CARPENTIERI, A.R. et al. Minireview on regulation of intestinal calcium absorption emphasis on molecular mechanisms of transcellular pathway. Digestion, v.77, p.22-34, 2008. 
RASCHKA, L.; DANIEL, H. Mechanisms underlying the effects of inulin-type fructans on calcium absorption in the large intestine of rats. Bone, v.37, p.728-735, 2005.

ROBERFROID, M.; GIBSON, G.R.; HOYLES, L. et al. Prebiotics effects: metabolic and health benefits. British Journal of Nutrition, v.104, p.S1-S63, 2010.

SCHEPPACH, W. Effects of short chain fatty acid on gut morphology and function. Gut, v.35, suppl. 1, p.S35-S38, 1994.

SCHOLZ-AHRENS, K.E.; SCHREZENMEIR, J. Inuli, oligofructose and mineral metabolism - experimental data and mechanism. British Journal of Nutrition, v.87, p.S179-S186, 2002.

SCHOLZ-AHRENS, K.E.; SCHREZENMEIR, J. Inulin and oligofructose and mineral metabolism: The evidence from animal trials. Journal of Nutrition, v.137, p.2513S-2523S, 2007.

TAKAHARA, S.; MOROHASHI, T.; SANO T. et al. Fructooligosaccharides consumption enhances femoral bone volume and mineral concentrations in rats. Journal of Nutrition, v.130, p.1792-1795, 2000.

TORRES, C.; ZARAZAGA, M. Antibiotics as growth promoters in animals. Are we on the right track? Gaceta Sanitaria, v.16, p.109-112, 2002.

VAN DER MERWE, B.J.; DUGMORE, T.J.; WALSH, K.P. The effect of flavophospholipol (Flavomycin ${ }^{\circledR}$ ) on milk production and milk urea nitrogen concentrations of grazing dairy cows. South African Journal of Animal Science, v.31, p.101-106, 2001.

VARLEY, P.F.; McCARNEY, C.; CALLAN J.J. et al. Effect of dietary mineral level and inulin inclusion on phosphorus, calcium and nitrogen utilisation, intestinal microflora and bone development. Journal of Science Food Agriculture, v.90, p.2447-2454, 2010.

VERDONK, J.M.; SHIM, S.B.; VAN LEEUWEN, P. et al. Application of inulin-type fructans in animal feed and pet food. British Journal of Nutrition, v.93, suppl.1, p.S125-S138, 2005.

VEEREMAN-WAUTERS, G.; STAELENS, S.; VAN DE BROEK, H. et al. Physiological and bifidogenic effects of prebiotic supplements in infant formulae. Journal Pediatric Gastroenterology and Nutrition, v.52, p.763-71, 2011.

VERBRUGGHE, A.; HESTA, M.; GOMMEREN, K. et al. Oligofructose and inulin modulate glucose and amino acid metabolism through propionate production in normal-weight and obese cats. British Journal of Nutrition, v.102, p.694-702, 2009.

YOUNES, H.; COUDRAY, C.; BELLANGER, J. et al. Effects of two fermentable carbohydrates (inulin and resistant starch) and their combination on calcium and magnesium balance in rats. British Journal of Nutrition, v.86, p.479-485, 2001. 